\title{
Environmental effects of historical charcoal burning associated with water-powered ferrous metallurgy (Mała Panew basin, southern Poland)
}

\author{
Paweł Rutkiewicz ${ }^{1}$, Ireneusz Malik ${ }^{2}$ \\ ${ }^{1}$ University of Silesia in Katowice, Faculty of Natural Sciences; ul. Bankowa 12, 40-007 Katowice, Poland; \\ e-mail: rutkiewiczpawel33@gmail.com; ORCID ID: 0000-0001-9347-5600 \\ ${ }^{2}$ University of Silesia in Katowice, Faculty of Natural Sciences; ul. Bankowa 12, 40-007 Katowice, Poland; \\ e-mail:ireneusz.malik@us.edu.pl; ORCID ID:0000-0002-8244-6203
}

(C) 2019 Authors. This is an open access publication, which can be used, distributed and reproduced in any medium according to the Creative Commons CC-BY 4.0 License requiring that the original work has been properly cited.

Received: 19 June 2019; accepted: 23 September 2019; first published online: 18 November 2019

\begin{abstract}
The main aim of this study was the reconstruction of the environmental changes (identifiable at this stage of research) resulting from large-scale charcoal production for the needs of historical water-powered metallurgy in selected sites in the Mała Panew basin. The identification of the remains of charcoal hearths was carried out by analysing shaded relief models. Shaded relief models were created from data from Airborne Laser Scanning (LIDAR). In order to verify the charcoal hearth remains identified in digital images, ground proofing was carried out. The charcoal hearth remains were subjected to sampling. Fragments of charcoal were extracted from the samples, which were then sent for analysis to identify tree species. In order to determine the age of chosen charcoal hearth remains, 10 charcoal pieces were submitted for radiocarbon dating. The following taxa were identified: Scots pine (Pinus sylvestris), alder (Alnus sp.), birch (Betula sp.), oak (Quercus sp.), Norway spruce / larch (Picea abies / Larix sp.), Silver fir (cf. Abies alba) and ash (Fraxinus excelsior). The taxa identified are dominated by Scots pine (56\%). This research demonstrates that valuable wood of deciduous species might have been overexploited at the initial stage of metallurgical production and very quickly exhausted, being replaced by fast-growing coniferous species. The excessive exploitation of the forests might have had negative environmental effects such as the transformation/modification of the species composition of the forest cover, significant deforestation of exploited areas, intensification of floods or the initiation of aeolian transport of sands. All the charcoal hearth remains investigated date to the period from 1677 to 1957 AD.
\end{abstract}

Keywords: human impact, landscape transformation, deforestation, charcoal hearth remains

\section{INTRODUCTION}

Apart from the availability of iron ore, a continuous supply of charcoal was one of the basic factors enabling the intensive development of historical water-powered metallurgical activity. With the passing of time, high demand for charcoal led to significant environmental change, e.g. complete transformation of natural forest communities into anthropogenic plantings (Knapp et al. 2015). Charcoal hearths were domed piles of wood constructed on a circular plan, which were covered with coniferous (70\%) Scots pine (Pinus sylvestris) (30\%); or brushwood and soil (Raab et al. 2015), depending on the available material. Charcoal hearths reached a height of about 2-3 $\mathrm{m}$ and had a diameter of about 8 to even $30 \mathrm{~m}$ (Tyrol 2011). The wood in charcoal hearths was ignited and then the pyrolysis process took place, which could last up to 20 days (Hirsch et al. 2018). After the charcoal burning process, charcoal hearth remains have survived as small elevations inside of which charcoal fragments 
are present, which is typical for flatlands while on sloped terrain there is normally a well-established step (Raab et al. 2017b). Analysis of charcoal remains enables one to identify the tree species used for charcoal burning in order to study the exploitation of the forest and the impact of charcoal production on soil properties (e.g. Nelle 2003, Deforce et al. 2013, Knapp et al. 2015, Dupin et al. 2017, Hazell et al. 2017, Ludemann et al. 2017, Py-Saragaglia et al. 2017, Hirsch et al. 2018). Research on charcoal hearth remains and historical charcoal burning has also been carried out in Poland (Rutkiewicz et al. 2019). However, a study permitting a broader recognition of the species used for charcoal burning and investigating the environmental effects of this type of activity has not yet been conducted. The valley of the Mała Panew River was selected for study because a large number of charcoal hearth remains were identified within it during pilot studies (Rutkiewicz et al. 2019). The main aim of this study was the reconstruction of the environmental changes (identifiable at this stage of research) that resulted from large-scale charcoal production for the needs of historical water-powered metallurgy in selected sites in the Mała Panew basin. Detailed objectives were assumed: to determine the dimensions of selected charcoal hearth remains, their internal structure and to determine their age (1), the identification of tree species used for charcoal burning from charcoal hearth remains (2), to estimate changes in forest area resulting from charcoal burning (3), to attempt to identify other environmental effects of charcoal burning - the intensification of floods and triggering aeolian processes in the Mała Panew River basin (4).

\section{STUDY AREA}

The study was conducted in the upper part of the Mała Panew River basin (Fig. 1). The Mała Panew is a meandering, sand-bedded river with a mean annual discharge of $8.97 \mathrm{~m}^{3} / \mathrm{s}$ and a ground-rainsnow regime. Mała Panew drains $2,037 \mathrm{~km}^{2}$ of the Opole Plain, which is part of the Silesian Lowland, and its source section lies within the Silesian Upland (Kondracki 1998). The riverbed is cut in dozen-or-so metre thick fluvioglacial sands of the Riss glaciation, filling the reduction between the upper and middle Triassic thresholds (Włodek 1976). The river is characterised by the occurrence of numerous meanders with different radii of curvature, typical of areas with forested banks. There are four terraces in the valley: a Pleistocene terrace (4-7 m), two Holocene terraces (3-4 $\mathrm{m}$ and $1.5-3.0 \mathrm{~m})$ and the flood plain $(0.5-1.5 \mathrm{~m})$. The terraces of the Mała Panew River are covered with the agriculture of pinewoods (Pinus sylvestris), while on the floodplain there are patches of ash-alder riparian forest (Circaeo-Alnetum), poplar-willow riparian forest (Salici Populetum) and alder swamp (Ribonigri-Alnetum) (Dynowska 1971, Malik 2006, 2008).

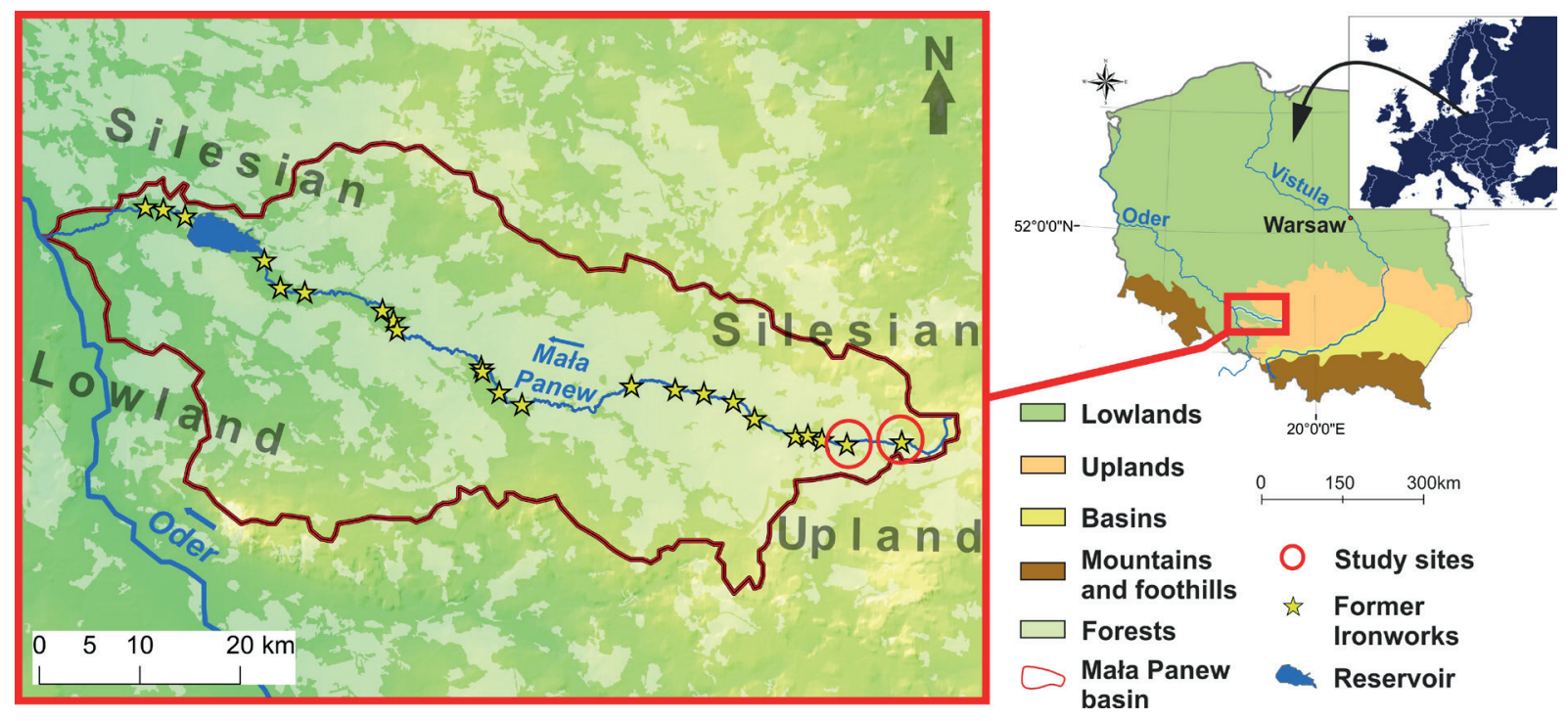

Fig. 1. Location of study areas (based on data from official website of Polish State Forests: www.bdl.lasy.gov.pl) 
The oldest bloomeries or other evidence of iron metallurgy in the Mała Panew River valley were documented at 10 archaeological sites of the Przeworsk culture (late Roman period, $2^{\text {nd }}-4^{\text {th }}$ centuries $\mathrm{AD}$ ). However, water-powered metallurgy began here around the $14^{\text {th }}$ century. In a small part of the Opole Plain, Juros (2012) indicates 38 places where iron was produced in the $15^{\text {th }}-20^{\text {th }}$ centuries. Another 10 metallurgical settlements in neighbouring areas are mentioned by Goszyk (2001). Certainly, it is well known that there were 10 blast furnaces for iron smelting and 52 finery forges with water-powered hammers along Mała Panew River (Rajman 1962, Malik et al. 2015). The intensive development of metallurgy took place from the 16th to the beginning of the $18^{\text {th }}$ century, a period of development that was caused by the constant demand for iron (Żebracka-Prus 2010). At the time, bloomeries were established close to bog iron deposits. The Thirty Years War (16181648) contributed to the partial collapse of metallurgy along the Mała Panew River. The revival and re-development of metallurgy took place at the turn of the $18^{\text {th }}$ and $19^{\text {th }}$ centuries thanks to colonisation of the area by Frederick II (Friedrich II von Hohenzollern). In the $18^{\text {th }}$ century, blast furnace technology was introduced in the Mała Panew River basin. This technology permitted a higher melting temperature to be obtained and therefore a higher efficiency of production (Żebracka-Prus 2010). Water-powered metallurgy in the Mała Panew valley functioned well until the mid- $19^{\text {th }}$ century, when hard coal was introduced to metallurgy. This resulted in a shift in the location of smelting plants to areas adjoining hard coal mining sites and eventually led to the collapse of the iron industry along the Mała Panew River. Two study sites were selected for detailed research: Kalety and Cynków. Five charcoal hearth remains were selected at each site. The research area was chosen due to the high density of metallurgical plants using charcoal which existed in the past (Niedźwiedzki 2012), as well as the good preservation of the remains of charcoal hearths.

\section{METHODS}

\section{Analysis of the images from LIDAR data}

In previous research on the catchment area selected, the Mała Panew River, as many as 166,356 charcoal hearth remains were identified in an area of $902 \mathrm{~km}^{2}$. To date, this is the only confirmed case in Europe, and even in the world, of the occurrence of such a high concentration of remains of charcoal hearths over a relatively large area (Rutkiewicz et al. 2019). Nevertheless, continuous research on charcoal hearth remains reveals their high density both on smaller and large surfaces, e.g. Raab et al. (2017a).

The identification of charcoal hearth remains was carried out by analysing shaded relief models. Shaded relief models were created on the basis of data from Airborne Laser Scanning (LIDAR). The remains of a typical charcoal hearth in the study area was $14 \mathrm{~m}$ in diameter, with a small elevation in the centre of up to about $0.5 \mathrm{~m}$ in height and surrounded by shallow hollows $(10-20 \mathrm{~cm})$ (Fig. 2). There were from 4 to 9 hollows with a diameter of 2-3 $\mathrm{m}$ around the central elevation (Rutkiewicz et al. 2019). In this study, the research area was reduced to just two sites located in the upper part of the Mała Panew River basin (Fig. 1). Areas were selected around the former ironworks near the town of Kalety and around the former ironworks near the village of Cynków. Based on shaded relief models for each site, 5 well-preserved charcoal hearth remains were selected for detailed research (Figs. 3, 4). The charcoal hearth remains selected were located as close as possible to the bottom of the Mała Panew River valley.

\section{Field identification and sampling of charcoal hearth remains}

In order to verify the charcoal hearth remains identified in digital images, ground proofing was carried out. Charcoal hearth remains were found using geographical coordinates on the GPS receiver. During the proofing, the diameter including the hollows, the diameter of the hollows themselves, the number of hollows and the height of the central elevation were measured for each chosen charcoal hearth remains. Charcoal hearth remains were considered to be an elliptical form with a slight elevation in the centre (up to $0.5 \mathrm{~m}$ ) surrounded by shallow depressions $(10-20 \mathrm{~cm}$ deep) located around the elevation (Fig. 2A, B). Two test pits were made in each charcoal hearth remain (one in the centre, the other in the hollow around the elevation in the centre). 


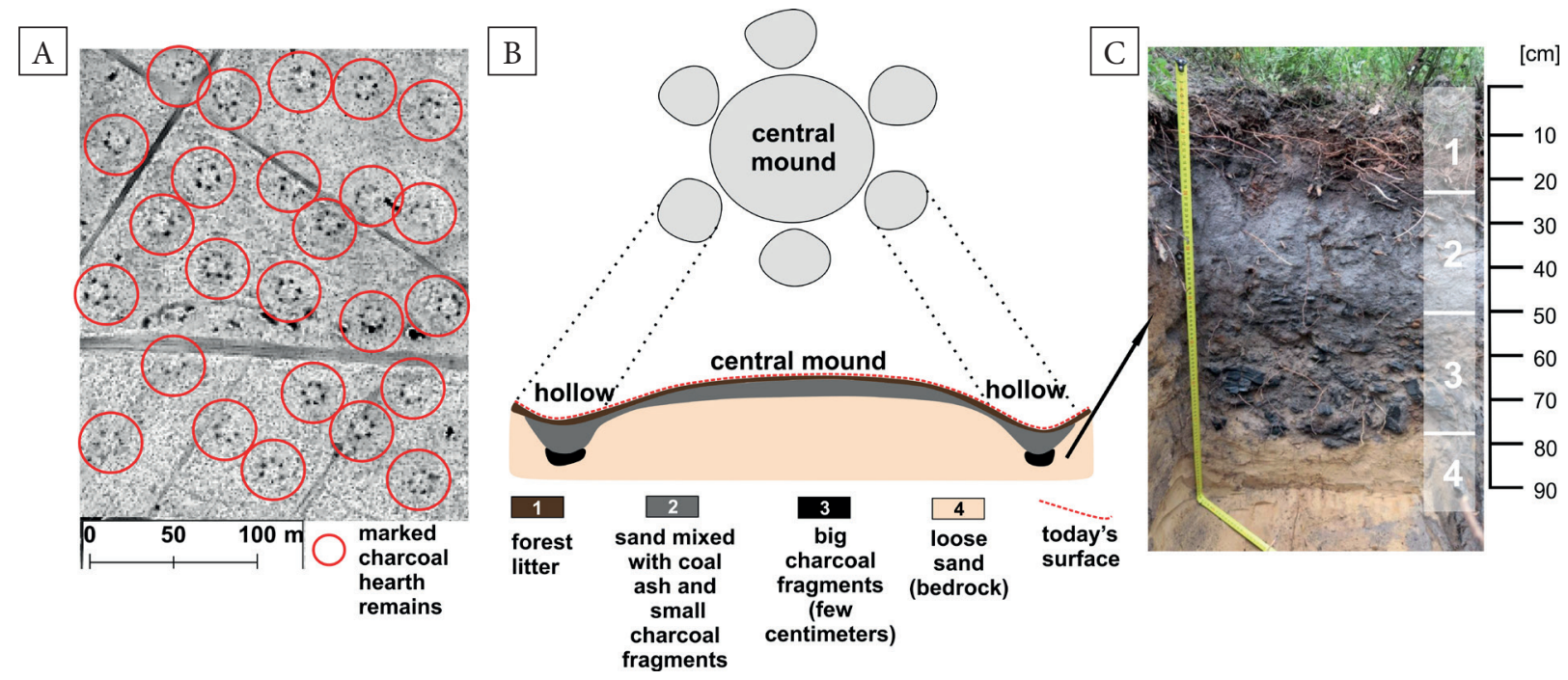

Fig. 2. Charcoal hearth remains identified on the shaded relief model (A); plan view of the typical remains of a charcoal hearth and cross-section through a charcoal hearth remains (B); photograph of sediments inside the charcoal hearth remains (C)

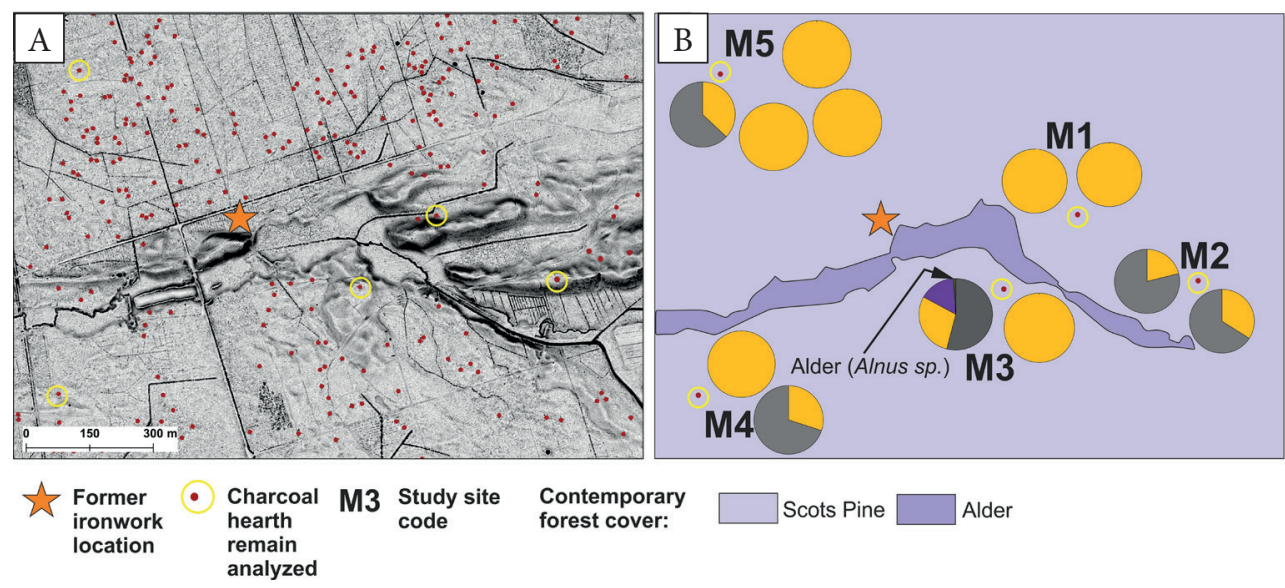

Taxa identified in charcoal hearth remains:

Fig. 3. Cynków study site on a shaded relief model (A); taxa identified in charcoal hearth remains and contemporary forest cover in the background (B) (based on data from official website of Polish State Forests: www.bdl.lasy.gov.pl)

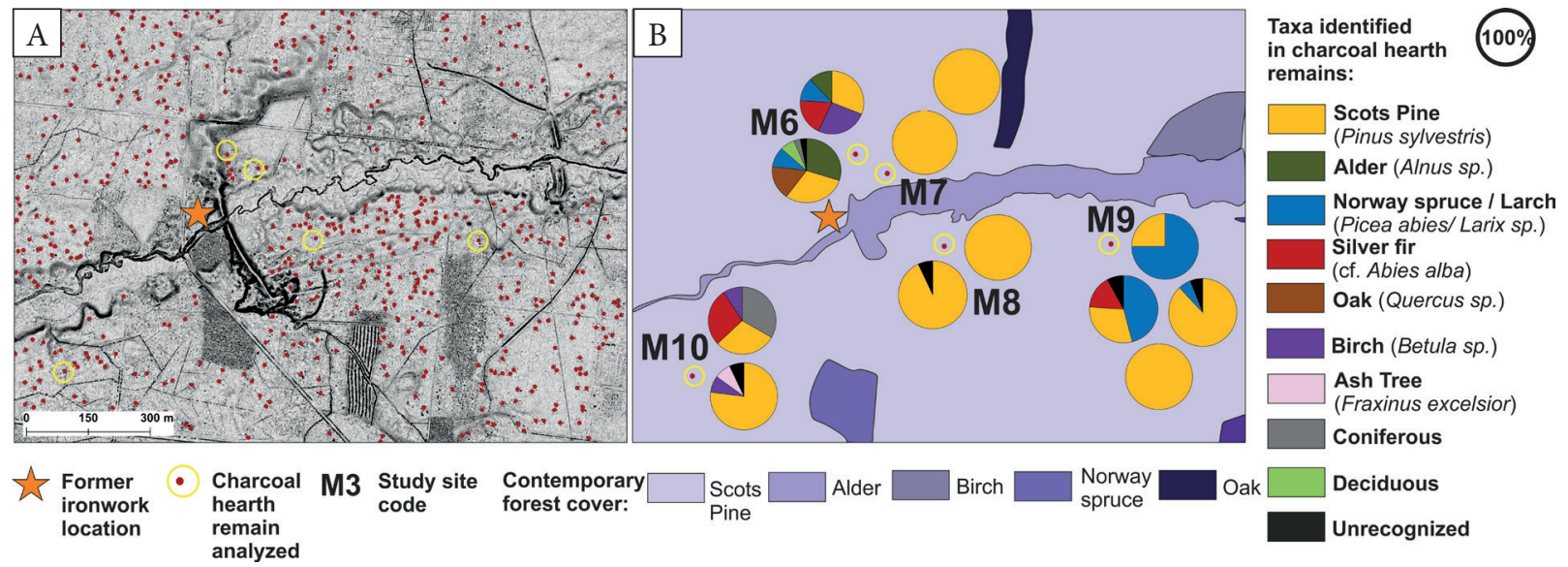

Fig. 4. Kalety study site on a shaded relief model (A); taxa identified in charcoal hearth remains and contemporary forest cover in the background (B) (based on data from official website of Polish State Forests: www.bdl.lasy.gov.pl) 
If there was a layer of charcoal or charcoal mixed with the sand in the sediment profile created (Fig. 2C), it was assumed that a charcoal hearth had certainly operated in this place in the past. The charcoal hearth remains identified were subjected to sampling. For four charcoal hearth remains at each site, two sampling zones were designated within the single charcoal hearth remains, while for one charcoal hearth remains at each site, four sampling zones were designated to obtain more detailed research material. In each designated zone, a $50 \times 50 \mathrm{~cm}$ wide pit was made, and then a profile of sediments was revealed in which a sample of $500 \mathrm{~cm}^{3}$ was obtained from a layer composed of charcoal or charcoal mixed with sand. Each pit was deepened and the profile was made at a depth of at least $0.5 \mathrm{~m}$ below the charcoal layer to exclude the possibility of the re-occurrence of the charcoal layer below the charcoal level previously identified. At the Woźniki site, from five charcoal hearth remains, a total of 12 samples were obtained with a volume of $6,000 \mathrm{~cm}^{3}$. The same number of samples, with the same volume, was obtained at the Kalety site. In the next stage, fragments of charcoal were extracted from the samples, which were then sent for analysis to identify the tree species from which the charcoal was made.

\section{Palaeobotanical analysis}

Initially, the samples were sieved (sieve size $2 \mathrm{~mm}$ ) to separate fragments of charcoal from the mineral fraction. In most cases, many large-sized pieces of charcoal were identified which is especially useful for paleobotanical analyses. Fragments which had at least one axis that was $2 \mathrm{~cm}$ long were selected for analysis. For five charcoal hearth remains at the Woźniki site, a total of 276 pieces of charcoal with a total weight of 2,279 grams were identified. For five charcoal hearth remains at the Kalety site, a total of 217 pieces of charcoal with a total weight of 4,575 grams were identified. Each charcoal fragment analysed was measured (along the longest dimension) and the samples were split to obtain surfaces that would allow inspection of anatomical features in the transverse, tangential and radial sections. The charcoal underwent taxonomic identification based on their preserved wood anatomy. The samples were analysed at a magnification range of $100 \times$ to $500 \times$ in reflected light using the Olympus BX53M metallographic microscope and the Stream Essentials $2.1 \mathrm{mi}$ cro-imaging software. The anatomical features observed were then compared with modern comparative specimens (from the Silesian Museum, Katowice's own collection) and data from patterns included in the keys for recognising tree species (Schweingruber 1990).

\section{Radiocarbon dating of charcoal hearth remains}

In order to determine the age of 10 chosen charcoal hearth remains, 10 charcoal pieces (one from each charcoal hearth remains) were submitted for radiocarbon dating. Conventional dating of 9 charcoal pieces was performed at the Absolute Dating Laboratory in Krakow (laboratory code: MKL). One charcoal sample, due to its small size, was dated using the AMS method at the Radiocarbon Laboratory of the Silesian University of Technology in Gliwice (laboratory code: GdA). The radiocarbon ages were calibrated using the Oxcal program, version 4.2 based on the Intcal $13.14 \mathrm{c}$ database (Reimer et al. 2013) and with a standard deviation of 2 sigma (95\% probability).

\section{RESULTS AND DISCUSSION}

\section{Dimensions of charcoal hearth remains and the sediments inside them}

The locations of the charcoal hearth remains identified are marked in Figures 3 and 4. The results of measurements of the chosen charcoal hearth remains are included in Table 1. The diameters of the charcoal hearth remains range from 11.0 to $16.5 \mathrm{~m}$. The number of hollows surrounding the central raised area in the charcoal hearth remains is from 4 to 7 . The hollows have a diameter of $2-3 \mathrm{~m}$. In the upper part of the sediment profile, below the organic level, there is an organic-mineral layer consisting of charcoal and sand. The layer of charcoals inside the charcoal hearth remains was present from 30 to even $80 \mathrm{~cm}$ depth. Loose sand was found directly below the charcoal layer (Fig. 2). 
Table 1. Taxa identification and radiocarbon dates from the charcoal hearth remains on the Cynków and Kalety sites and their morphometric characteristics

\begin{tabular}{|c|c|c|c|c|c|c|c|c|c|}
\hline $\begin{array}{l}\text { Char- } \\
\text { coal } \\
\text { hearth } \\
\text { remain }\end{array}$ & $\begin{array}{l}\text { Diam- } \\
\text { eter of } \\
\text { charcoal } \\
\text { hearth } \\
\text { remain } \\
\text { [m] }\end{array}$ & $\begin{array}{l}\text { Number } \\
\text { of hol- } \\
\text { lows and } \\
\text { average } \\
\text { diameter } \\
{[\mathrm{m}]}\end{array}$ & $\begin{array}{c}\text { Depth } \\
\text { of sam- } \\
\text { pling } \\
{[\mathrm{cm}]}\end{array}$ & $\begin{array}{l}\text { Num- } \\
\text { ber of } \\
\text { char- } \\
\text { coal } \\
\text { pieces }\end{array}$ & $\begin{array}{l}\text { Weight } \\
\text { of char- } \\
\text { coal } \\
\text { pieces } \\
\text { [g] }\end{array}$ & $\begin{array}{c}\text { Taxa identification and percentage values } \\
\text { for each taxon }\end{array}$ & $\begin{array}{l}\text { Age } \\
\text { conv. } \\
{[B P]}\end{array}$ & $\begin{array}{l}\text { Age cal } \\
\text { AD } \\
(95.4 \%)\end{array}$ & $\begin{array}{l}\text { Labo- } \\
\text { ratory } \\
\text { code }\end{array}$ \\
\hline \multicolumn{10}{|c|}{ Study site - Cynków } \\
\hline \multirow{2}{*}{ M 1} & \multirow{2}{*}{11} & \multirow{2}{*}{$5(2)$} & $60-70$ & 17 & 241 & Scots pine (Pinus sylvestris) (100\%) & \multirow{2}{*}{$80 \pm 35$} & \multirow{2}{*}{$\begin{array}{c}1682- \\
1930\end{array}$} & \multirow{2}{*}{$\begin{array}{c}\text { MKL- } \\
4163\end{array}$} \\
\hline & & & $60-70$ & 18 & 214 & Scots pine (Pinus sylvestris) (100\%) & & & \\
\hline \multirow{2}{*}{ M 2} & \multirow{2}{*}{12} & \multirow{2}{*}{$4(2.5)$} & $60-70$ & 28 & 161 & $\begin{array}{c}\text { coniferous (79\%) } \\
\text { Scots pine (Pinus sylvestris) (21\%) }\end{array}$ & \multirow{2}{*}{$\begin{array}{l}130 \\
\pm 35\end{array}$} & \multirow{2}{*}{$\begin{array}{c}1670- \\
1943\end{array}$} & \multirow{2}{*}{$\begin{array}{c}\text { MKL- } \\
4164\end{array}$} \\
\hline & & & $60-70$ & 41 & 150 & $\begin{array}{c}\text { coniferous (66\%) } \\
\text { Scots Pine (Pinus sylvestris) }(34 \%) \\
\end{array}$ & & & \\
\hline \multirow[b]{2}{*}{ M 3} & \multirow[b]{2}{*}{14} & \multirow[b]{2}{*}{$4(2.5)$} & $40-50$ & 11 & 247 & Scots pine (Pinus sylvestris) (100\%) & \multirow[b]{2}{*}{$60 \pm 35$} & \multirow[b]{2}{*}{$\begin{array}{c}1690- \\
1925\end{array}$} & \multirow[b]{2}{*}{$\begin{array}{c}\text { MKL- } \\
4165\end{array}$} \\
\hline & & & $40-50$ & 38 & 354 & $\begin{array}{c}\text { coniferous (54\%) } \\
\text { Scots pine (Pinus sylvestris) }(29 \%) \\
\text { Birch (Betula sp.) (16\%) } \\
\text { Alder (Alnus sp.) }(1 \%) \\
\end{array}$ & & & \\
\hline \multirow[b]{2}{*}{ M 4} & \multirow[b]{2}{*}{14} & \multirow[b]{2}{*}{$5(3)$} & $60-70$ & 13 & 142 & Scots pine (Pinus sylvestris) (100\%) & \multirow[b]{2}{*}{$\begin{array}{l}120 \\
\pm 35\end{array}$} & \multirow[b]{2}{*}{$\begin{array}{c}1677- \\
1940\end{array}$} & \multirow[b]{2}{*}{$\begin{array}{c}\text { MKL- } \\
4166\end{array}$} \\
\hline & & & $60-70$ & 33 & 117 & $\begin{array}{c}\text { coniferous (70\%) } \\
\text { Scots Pine (Pinus sylvestris) }(30 \%)\end{array}$ & & & \\
\hline \multirow{4}{*}{ M 5} & \multirow{4}{*}{12} & \multirow{4}{*}{$4(2.5)$} & $60-70$ & 38 & 148 & $\begin{array}{c}\text { coniferous (63\%) } \\
\text { Scots pine (Pinus sylvestris) }(37 \%) \\
\end{array}$ & \multirow{4}{*}{$110 \pm 30$} & \multirow{4}{*}{$\begin{array}{c}1681- \\
1938\end{array}$} & \multirow{4}{*}{$\begin{array}{c}\text { GdA- } \\
5749\end{array}$} \\
\hline & & & $50-60$ & 12 & 254 & Scots pine (Pinus sylvestris) (100\%) & & & \\
\hline & & & $40-70$ & 17 & 134 & Scots pine (Pinus sylvestris) (100\%) & & & \\
\hline & & & $50-70$ & 10 & 117 & Scots pine (Pinus sylvestris) (100\%) & & & \\
\hline & & & & & Study & site - Kalety & & & \\
\hline M 6 & 13.5 & $7(2)$ & $35-40$ & 30 & 495 & $\begin{array}{c}\text { Scots pine (Pinus sylvestris) (30\%) } \\
\text { Alder (Alnus sp.) }(30 \%) \\
\text { Oak (Quercus sp.) (17\%) } \\
\text { Norway spruce / Larch (Picea abies / } \\
\text { Larix sp.) }(10 \%) \\
\text { deciduous }(7 \%) \\
\text { coniferous }(3 \%) \\
\text { unrecognized }(3 \%)\end{array}$ & $70 \pm 35$ & $\begin{array}{c}1691- \\
1924\end{array}$ & $\begin{array}{c}\text { MKL- } \\
4158\end{array}$ \\
\hline & & & $55-65$ & 16 & 342 & $\begin{array}{c}\text { Scots pine (Pinus sylvestris) (31\%) } \\
\text { Birch (Betula sp.) (26\%) } \\
\text { Silver fir (cf. Abies alba) (19\%) } \\
\text { Norway spruce / Larch (Picea abies / } \\
\text { Larix sp.) (12\%) } \\
\text { Alder (Alnus sp.) (12\%) }\end{array}$ & & & \\
\hline M 7 & 155 & $5(0)$ & $50-55$ & 12 & 390 & Scots pine (Pinus sylvestris) (100\%) & 100 & $1681-$ & MKL- \\
\hline $\mathrm{M} /$ & 15.5 & $5(2)$ & $55-60$ & 15 & 391 & Scots pine (Pinus sylvestris) (100\%) & \pm 35 & 1938 & 4159 \\
\hline & & & $30-35$ & 15 & 470 & Scots pine (Pinus sylvestris) (100\%) & & & \\
\hline M 8 & 155 & $5(2)$ & $35-40$ & 15 & 434 & $\begin{array}{c}\text { Scots pine (Pinus sylvestris) (93\%) } \\
\text { unrecognized (7\%) }\end{array}$ & $\begin{array}{r}100.5 \\
+0.5 \%\end{array}$ & $1697-$ & MKL- \\
\hline & & & $30-55$ & 16 & 278 & $\begin{array}{c}\text { Norway spruce / Larch (Picea abies / } \\
\text { Larix sp.) }(75 \%) \\
\text { Scots pine (Pinus sylvestris) (25\%) }\end{array}$ & pMC & 1957 & 4160 \\
\hline & & & $40-50$ & 16 & 291 & $\begin{array}{c}\text { Scots pine (Pinus sylvestris) (88\%) } \\
\text { Norway spruce / Larch (Picea abies / } \\
\text { Larix sp.) }(6 \%) \\
\text { unrecognized (6\%) }\end{array}$ & & & \\
\hline & & & $35-80$ & 17 & 426 & Scots pine (Pinus sylvestris) $(100 \%)$ & & & \\
\hline M 9 & 16.5 & $5(2.5)$ & $50-70$ & 13 & 244 & $\begin{array}{c}\text { Norway spruce / Larch (Picea abies / } \\
\text { Larix sp.) (46\%) } \\
\text { Scots pine (Pinus sylvestris) (30\%) } \\
\text { Silver fir (cf. Abies alba) (16\%) } \\
\text { unrecognized (8\%) }\end{array}$ & $30 \pm 35$ & $\begin{array}{c}1694- \\
1919\end{array}$ & $\begin{array}{c}\text { MKL- } \\
4162\end{array}$ \\
\hline & & & $40-50$ & 39 & 380 & $\begin{array}{c}\text { coniferous (46\%) } \\
\text { Scots pine (Pinus sylvestris) (18\%) } \\
\text { Birch (Betula sp.) (15\%) } \\
\text { Silver fir (cf. Abies alba) (16\%) } \\
\text { unrecognized (5\%) }\end{array}$ & & & \\
\hline M 10 & 14.5 & $5(2.5)$ & $40-50$ & 13 & 434 & $\begin{array}{l}\text { Scots pine (Pinus sylvestris) }(77 \%) \\
\text { Birch (Betula sp.) }(8 \%) \\
\text { Ash tree (Fraxinus excelsior) }(8 \%) \\
\text { unrecognized }(7 \%)\end{array}$ & $70 \pm 35$ & $\begin{array}{c}1688- \\
1927\end{array}$ & $\begin{array}{c}\text { MKL- } \\
4161\end{array}$ \\
\hline
\end{tabular}




\section{Identification of tree species used for charcoal burning}

The results of the palaeobotanical analysis of charcoals are presented in Table 1. Both the number and weight of the charcoal pieces analysed from each charcoal hearth remains were presented. On the basis of the results obtained, it can be assumed that both coniferous $(83 \%)$ and deciduous (16\%) species were used for charcoal burning. This was mainly based on coniferous trees (predominantly Scots pine), probably due to the larger areas occupied by these species. Scots pine is the dominant species in all the charcoal hearth remains examined (279 fragments $-56 \%$ of the total). In the case of a group containing a large number of charcoal fragments, it was only recognised that they came from the burning of coniferous trees (133 fragments $-27 \%$ of the total). In addition, 24 fragments of spruce/larch wood were identified (5\% of the total), 17 fragments of birch wood (4\% of the total), 14 fragments of alder wood (3\% of the total), 11 fragments of fir wood ( $2 \%$ of the total), 5 fragments of oak wood ( $1 \%$ of the total). A small admixture of species is wood recognised as from deciduous trees ( 2 fragments) and ash wood (1 fragment). For 7 fragments, species recognition was not possible ( $1 \%$ of the total). On the basis of the results of the palaeobotanical analysis, it is known that the wood used to burn charcoal in the charcoal hearths was mainly pine. The potential vegetation of the study area is mainly pine forests, pine-oak forests and oak-hornbeam forests (Matuszkiewicz et al. 1995). On the other hand, the area currently studied is mainly covered by monocultures of planted pine and alder communities in wetlands (Figs. 3, 4). Small areas are occupied by birch, spruce, and oak (Figs. 3, 4). It may be noted that the current forest composition partly corresponds to the natural vegetation, which should be mixed communities. In the Kalety site, there is a greater variety of species identified compared to the previous site. In addition to Scots pine, numerous species of deciduous trees occur here. It is possible that the deciduous species, constituting a small admixture of the current forests, are remnants of larger communities from the past. They could be significantly depleted as a result of the charcoal burning. Hardwood was a very attractive feedstock in the context of charcoal production. So-called hard charcoal was produced from this type of wood whereas so-called soft charcoal was produced from coniferous species. Hard charcoal was more valuable and more desirable because it permitted a higher temperature to be reached in the blast furnace (Surmiński 2002). It is known that in the Middle Ages, in France and Germany, hornbeam, oak, and beech wood were burnt in charcoal hearths (Schmidt et al. 2016, Dupin et al. 2017). In some areas, the production of charcoal even caused a complete transformation of natural forest communities into cultivated forests with altered species composition (Reichmuth 1986, Knapp et al. 2015).

\section{Change in forest areas}

\section{as a result of charcoal burning and the dating of selected charcoal hearth remains}

The number of charcoal hearth remains identified during the previous study (Rutkiewicz et al. 2019), indicates that charcoal burning had a very large impact in changing of the forest plant communities in the study areas over past centuries. In fact, the whole surface of the Mała Panew River basin is covered with numerous remains of charcoal hearths. This means that the forest plant communities have been completely eradicated over the centuries, for the needs of metallurgy. Periods of forest thinning clearly became more intense during the periods when metallurgy developed. The first such period took place from the $16^{\text {th }}$ to the beginning of the $17^{\text {th }}$ century, as Roździeński writes in his metallurgical poem from 1612. It is known from the same poem that at the turn of the $16^{\text {th }}$ and $17^{\text {th }}$ centuries most of the ironworks were located in the basin of the upper course of the Mała Panew and that they were the most prosperous plants in Silesia. Such a large concentration of ironworks in a relatively small area had to lead to significant losses of forest area. The Thirty Years War caused a partial collapse of the metallurgy alongside the Mała Panew River, but metallurgy had already begun to develop again in the $18^{\text {th }}$ century (Żebracka-Prus 2010). It was a particularly intensive period 
of development because large furnaces began to be built and they permitted an improvement in the raw material smelting process as well as an increase in production. Increasing production also caused a greater demand for fuel for the blast furnaces, which was charcoal. As a result, more wood was obtained than beforehand. Deforestation at that time assumed a significant scale, which had to have negative environmental effects. Considering the technology used when water-powered metallurgy commenced, and then the invention of blast furnaces, it should be concluded that the exploitation of the areas of forest was progressing gradually, culminating in the $18^{\text {th }}-19^{\text {th }}$ centuries. This is also confirmed by the results of the dating of charcoal hearth remains. All the dates obtained range from 1677 to $1957 \mathrm{AD}$, so they fall into the second period of intensive development of the metallurgy alongside the Mała Panew River. All the radiocarbon dates for the selected charcoal hearth remains are presented in Table 1 . The wide range of probabilities for the calibrated dates is due to the impact of the so-called Suess effect on the calibration curve. The radiocarbon dates indicate that all charcoal hearth remains come from one period. Considering that the production of charcoal for the needs of metallurgy began here more or less in the fourteenth century, it can be assumed that older charcoal hearth remains have been destroyed or occur in other parts of the Mała Panew River basin. Another scenario is also possible. When water-powered metallurgy began, charcoal was produced right beside the smelting centre (Schmidt et al. 2016). After depleting the forests in this area, the production of charcoal moved to more distant parts of the forest. Due to the fact that the charcoal hearth remains selected are located close to the bottom of the valley where metallurgical centres were established, they should be relatively old. However, this is not the case. This may mean that after cutting out the forests around the ironworks and transferring charcoal production to a more distant area, a renewal of forest resources took place. From the moment when the forest communities were sufficiently renewed to be able to obtain wood from them, the forests in the immediate vicinity of the bottom of the valley started to be exploited again. The use of such time-shifts and the change of place of production of charcoal is described by Deforce et al. (2013), based on the example of northern Belgium.

\section{Other environmental effects of charcoal burning}

In addition to the above-mentioned changes in the species composition of forest communities, gradual deforestation might have affected the reduction of water retention capacity in those areas where charcoal was burned, leading to an increase in flood events. This can be proved by, among other sources, written records relating information about an increased number of floods in the Mała Panew catchment (Goszyk 2001). The first flood recorded in historical sources took place in 1845. Another one occurred in 1856 and caused the dam of the pond in the Brusiek ironworks to burst. Large floods were noticed yet again in 1861, $1875,1877,1878,1879,1889,1891$, and the largest and most disastrous in 1903. This last flood destroyed many existing metallurgical ponds in the Mała Panew River basin (Goszyk 2001). Obviously, these floods are mainly caused by intense rainfall and slush melt, however, the lack of a forest cover or its large-scale thinning accelerated the outflow of water in the basin and made the floods more catastrophic (Punzet 1981). The cutting down of large areas of forest cover could also have had an impact on the aeolian transport activity of the Quaternary sands. Such a process was recorded in the area of Lower Lusatia where logs of charcoal from charcoal hearth remains, covered with a one-metre layer of sands, were dendrochronologically dated to 1850 (Rösler et al. 2012). But it must be noticed that this finding is rather the exception than the normal case. It is possible that the aeolian transport of sands has also been initiated in the study areas, especially given that the charcoal hearth remains on the dune surface, identified on digital images, are partially obliterated, perhaps by aeolian processes (Fig. 5). There are also more other environmental effects especially on soil physical and chemical properties which was proved by Schneider et al. $(2018,2019)$ and Hirsch et al. (2018). These issues should be also examined in the future, for the Mała Panew River basin. 


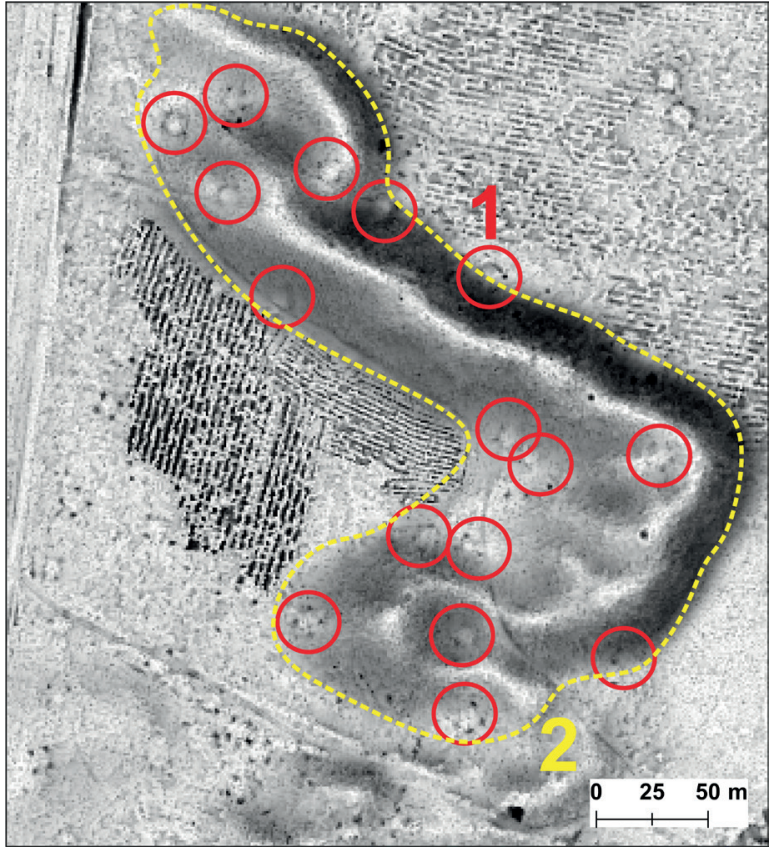

Fig. 5. An example of charcoal hearth remains visible on the dune surface: 1 - partially obliterated charcoal hearth remains marked in red circles; 2 - dune area marked with a dashed yellow line

\section{CONCLUSIONS}

1. As a result of charcoal burning, natural forests were cut down in the Mała Panew River valley from the $17^{\text {th }}$ century onwards. It is possible that the destruction of natural habitats took place much earlier.

2. Burning charcoal in the Mała Panew valley caused large-scale cutting of trees. Coniferous $(83 \%)$ and deciduous (16\%) species were used for charcoal production in the study area in the Mała Panew River basin. The following taxa were identified: Scots pine (Pinus sylvestris), alder (Alnus sp.), birch (Betula sp.), oak (Quercus sp.), Norway spruce / larch (Picea abies / Larix sp.), Silver fir (cf. Abies alba) and ash (Fraxinus excelsior).

3. The majority of the taxa identified are dominated by Scots pine (56\%), which might indicate the deliberate choice of this species for charcoal burning or the high availability of this species in the past. However, the research proves that valuable wood of deciduous species might have been overexploited at the initial stage of metallurgical production, exploited very rapidly and then replaced by fast-growing coniferous species.

4. Excessive exploitation of forests could have negative environmental effects such as an intensification of floods or the initiation of aeolian transport of sands.

This study was performed within the scope of the research Project no. 2017/25/N/ST10/01876 funded by the Polish National Science Centre (NCN). The authors wish also to thank the Polish National Forests for permission to conduct research in forest areas.

\section{REFERENCES}

Deforce K., Boeren I., Adriaenssens S., Bastiaens J., De Keersmaeker L., Haneca K. \& Vandekerkhove K., 2013. Selective woodland exploitation for charcoal production. A detailed analysis of charcoal kiln remains (ca. 13001900 AD) from Zoersel (northern Belgium). Journal of Archaeological Science, 40, 1, 681-689. DOI: 10.1016/ j.jas.2012.07.009.

Dupin A., Girardclos O., Fruchart C., Laplaige C., Nuninger L., Dufraisse A. \& Gauthier E., 2017. Anthracology of charcoal kilns in the forest of Chailluz (France) as a tool to understand Franche-Comte forestry from the mid-15 th to the early 20 th century AD. Quaternary International, 458, 200-213. DOI: 10.1016/j.quaint.2017.03.008.

Dynowska I., 1971. Typy reżimów rzecznych w Polsce. Prace Instytutu Geograficznego, 50, Zeszyty Naukowe Uniwersytetu Jagiellońskiego. Prace Geograficzne, 28, Uniwersytet Jagielloński, Państwowe Wydawnictwo Naukowe, Kraków.

Goszyk E., 2001. Kartki z dziejów Żelaznego Bruśka. Brusiek. Hazell Z., Crosby V., Oakey M. \& Marshall P., 2017. Archaeological investigation and charcoal analysis of charcoal burning platforms, Barbon, Cumbria, UK. Quaternary International, 458, 178-199. DOI: 10.1016/ j.quaint.2017.05.025.

Hirsch F., Schneider A., Bauriegel A., Raab A. \& Raab T., 2018. Formation, classification and properties of soils at two relict charcoal hearth sites in Brandenburg, Germany. Frontiers in Environmental Science, 6, 94, 1-15. DOI: 10.3389/fenvs.2018.00094.

Juros J.T., 2012. Historia, zabytki i ślady hutnictwa $w$ dolinie Małej Panwi na obszarze działania Stowarzyszenia LGD Kraina Dinozaurów: inwentaryzacja zabytkowych obiektów związanych z tradycjami hutniczymi. Stowarzyszenie Dolina Małej Panwi, Ozimek; Lokalna Grupa Działania "Kraina Dinozaurów", Spórok.

Knapp H., Nelle O. \& Kirleis W., 2015. Charcoal usage in medieval and modern times in the Harz Mountains Area, Central Germany: Wood selection and fast overexploitation of the woodlands. Quaternary International, 366, 51-69. DOI: 10.1016/j.quaint.2015.01.053. 
Kondracki J., 1998. Geografia regionalna Polski. Wydawnictwo Naukowe PWN, Warszawa.

Ludemann T., Brandt M., Kaiser L. \& Schick L., 2017. Variation of past wood use across local edaphic gradients reflects tree species ecology - Examples of the fine spatial resolution of kiln site anthracology. Quaternary International, 458, 224-232. DOI: 10.1016/j.quaint.2017.03.069.

Malik I., 2006. Contribution to understanding the historical evolution of meandering rivers using dendrochronological methods: example of the Mała Panew River in southern Poland. Earth Surface Processes and Landforms, 31, 10, 1227-1245. DOI: 10.1002/esp.1331.

Malik I., 2008. Dendrochronologiczny zapis współczesnych procesów rzeźbotwórczych kształtujących stoki i doliny rzeczne wybranych stref krajobrazowych Europy Srodkowej. Prace Naukowe Uniwersytetu Śląskiego w Katowicach, 2566, Wydawnictwo Uniwersytetu Śląskiego, Katowice.

Malik I., Wistuba M., Opała M., Franek M., Woskowicz-Ślęzak B., Mańczyk G. \& Tyrol C., 2015. Historical water-powered ferrous metallurgy reconstructed from tree-rings and lacustrine deposits (Mała Panew basin, southern Poland). Geochronometria, 42, 1, 79-90. DOI: 10.1515/geochr-2015-0004.

Matuszkiewicz W., Faliński J.B., Kostrowicki A.S., Matuszkiewicz J.M., Olaczek R. \& Wojterski T., 1995. Potencjalna roślinność naturalna Polski. Mapa przegladowa, 1:300 000. IGiPZ PAN, Warszawa, [on-line:] https:// www.igipz.pan.pl/Roslinnosc-potencjalna-zgik.html [access 13.04.2019].

Nelle O., 2003. Woodland history of the last 500 years revealed by anthracological studies of charcoal kiln sites in the Bavarian Forest, Germany. Phytocoenologia, 33,4, 667-682. DOI: 10.1127/0340-269X/2003/0033-0667.

Niedźwiedzki R., 2012. Od żelaza do silezaura. Historia górnictwa i odkrycia kręgowców triasowych w Krasiejowie. [in:] Jagt-Yazykova E., Jagt J.W.M., Bodzioch A. \& Konietzko-Mejer D. (eds.), Krasiejów: inspiracje paleontologiczne, Zakład Poligraficzno-Wydawniczy "Plik", Bytom, 6-27.

Punzet J., 1981. Zmiany w przebiegu stanów wody w dorzeczu górnej Wisły na przestrzeni 100 lat (1871-1970). Folia Geographica. Series Geographica Physica, 14, 5-28.

Py-Saragaglia V., Artigas R.C., Métailié J.P., Ancel B., Baron S., Paradis-Grenouillet S. \& Galop D., 2017. Late Holocene history of woodland dynamics and wood use in an ancient mining area of the Pyrenees (Ariège, France). Quaternary International, 458, 141-157. DOI: 10.1016/ j.quaint.2017.01.012.

Raab A., Takla M., Raab T., Nicolay A., Schneider A., Rösler H., Heußner K.-U., Bönisch E., 2015. Pre-industrial charcoal production in Lower Lusatia (Brandenburg, Germany): Detection and evaluation of a large charcoal-burning field by combining archaeological studies, GIS-based analyses of shaded-relief maps and dendrochronological age determination. Quaternary International, 367, 111-122. DOI: 10.1016/j.quaint.2014.09.041.
Raab A., Bonhage A., Schneider A., Raab T., Rösler H., Heußner K.U. \& Hirsch F., 2017a. Spatial distribution of relict charcoal hearths in the former royal forest district Tauer (SE Brandenburg, Germany). Quaternary International, 511, 153-165. DOI: 10.1016/j.quaint.2017.07.022.

Raab T., Hirsch F., Ouimet W., Johnson K.M., Dethier D. \& Raab A., 2017b. Architecture of relict charcoal hearths in northwestern Connecticut, USA. Geoarchaeology, 32(4), 502-510. DOI: 10.1002/gea.21614.

Rajman J., 1962. Rozwój ośrodków przemysłowych nad Mała Panwią. Wyd. "Śląsk", Katowice.

Reichmuth G., 1986. Die Produktion im ehemaligen Eisenhüttenwerk Peitz. Geschichte und Gegenwart des Bezirkes, Cottbus, 20, 103-112.

Reimer P.J., Bard E., Bayliss A., Beck J.W., Blackwell P.G., Ramsey C.B. \& Grootes P.M., 2013. IntCal13 and Marine13 radiocarbon age calibration curves $0-50,000$ years cal BP. Radiocarbon, 55, 4, 1869-1887. DOI: 10.2458/azu_ js_rc.55.16947.

Rösler H., Bönisch E., Schopper F., Raab T. \& Raab A., 2012. Pre-industrial charcoal production in southern Brandenburg and its impact on the environment. [in:]: Kluiving S. \& Guttmann-Bond E., Landscape Archaeology between Art and Science, Amsterdam, 167-178.

Roździeński W., 1612. Officina ferraria, abo huta y warstat $z$ kuźniami szlachetnego dzieła żelaznego. S. Kempini, Kraków.

Rutkiewicz P., Malik I., Wistuba M. \& Osika A., 2019. High concentration of charcoal hearth remains as legacy of historical ferrous metallurgy in southern Poland. Quaternary International, 512, 133-143. DOI: 10.1016/ j.quaint.2019.04.015.

Schmidt M., Mölder A., Schönfelder E., Engel F. \& Fortmann-Valtink W., 2016. Charcoal kiln sites, associated landscape attributes and historic forest conditions: DTM-based investigations in Hesse (Germany). Forest Ecosystems, 3, 8, 1-16. DOI: 10.1186/s40663-016-0067-6.

Schneider A., Hirsch F., Raab A., Raab T., 2018. Dye Tracer Visualization of Infiltration Patterns in Soils on Relict Charcoal Hearths. Frontiers in Environmental Sciences, 6, 143. DOI: $10.3389 /$ fenvs.2018.00143.

Schneider A., Hirsch F., Raab A. \& Raab T., 2019. The temperature regime of a charcoal-enriched land use legacy soil. Soil Science Society of America Journal, 83, 565-574. DOI: 10.2136/sssaj2018.12.0483.

Schweingruber F.H., 1990. Anatomy of European Woods. Haupt, Bern.

Surmiński J., 2002. Węglarstwo leśne, 1. Mielerze. Prace Komisji Nauk Rolniczych i Komisji Nauk Leśnych. Poznańskie Towarzystwo Przyjaciół Nauk, 92, 53-82.

Tyrol J., 2011. Dawno temu w lesie. Między Mała Panwia, Liswarta i Stobrawa. Castle, Nakło Śląskie - Kochanowice.

Włodek M., 1976. Plejstocen doliny Małej Panwi w rejonie Lublińca. Geological Quarterly, 20, 4, 839-852.

Żebracka-Prus A., 2010. Wybrane aspekty odrębności krajobrazu na przykładzie doliny Małej Panwi. Politechnika Śląska, Gliwice [Ph.D. dissertation]. 